\title{
Use of personal protective equipment in Canadian pediatric emergency departments
}

\author{
Sarah M. Reid, MD*; Ken J. Farion, MD*; Kathryn N. Suh, MD, MSc ; Tobey Audcent, MD*; \\ Nicholas J. Barrowman, $\mathrm{PhD}^{*}$; Amy C. Plint, MD, MSc
}

\section{ABSTRACT}

Objective: Numerous barriers to maintaining infection control practices through the use of personal protective equipment (PPE) exist in the emergency department (ED). This study examined the knowledge, self-reported behaviours, and barriers to compliance with infection control practices and the use of PPE in Canadian pediatric EDs.

Methods: A self-administered survey instrument consisting of 21 questions was developed and piloted for this study. The survey was mailed to all individuals listed in the Pediatric Emergency Research Canada database of physicians practicing pediatric emergency medicine in Canada.

Results: A total of 186 physicians were surveyed, and 123 (66\%) participated. Twenty-two percent of participants reported that they had never received PPE training and $32 \%$ had not been trained in the previous 2 years. Fifty-three percent reported being very or somewhat comfortable with their knowledge of transmission-based isolation practices. Participants were correct on a mean of 4.9 of 11 knowledge-based questions (SD 1.7). For scenarios assessing self-reported use of PPE, participants selected answers that reflected PPE use in accordance with national infection control standards in a mean of 1.0 of 6 scenarios (SD 1.0). Participants reported that they would be more likely to use PPE if patients were clearly identified prior to physician assessment, equipment was accessible, and PPE use was made a priority in their ED.

Conclusions: Knowledge and self-reported adherence to recommended infection control practices among Canadian pediatric emergency physicians is suboptimal. Early identification of patients requiring PPE, convenient access to PPE, and improved education regarding isolation and PPE practices may improve adherence.

\section{RÉSUMÉ}

Objectif: II existe de nombreux obstacles au maintien des pratiques de contrôle des infections par l'utilisation d'équipement de protection individuelle (EPI) dans les services d'urgences. Cette étude a examiné les connaissances, les comportements autodéclarés et les obstacles à l'observance des pratiques de lutte contre les infections et I'utilisation de l'EPI dans les services d'urgences pédiatriques au Canada.

Méthode: Un questionnaire autoadministré de 21 questions a été élaboré et mis à l'essai pour cette étude. Le sondage a été envoyé par courrier électronique à tous les médecins exerçant la médecine d'urgence pédiatrique au Canada qui sont répertoriés dans la base de données du Groupe de Recherche en Urgence Pédiatrique du Canada.

Résultats: 186 médecins ont été interrogés et 123 (66\%) ont participé à l'étude. Parmi tous les répondants, $22 \%$ ont déclaré n'avoir jamais reçu de formation sur I'EPI et $32 \%$ ont dit n'avoir pas reçu de formation au cours des 2 années précédentes. Par ailleurs, $53 \%$ ont déclaré être très ou assez à l'aise avec leur degré de connaissance des pratiques d'isolement axées sur la transmission. Les participants ont eu la bonne réponse sur une moyenne de 4,9 des 11 questions fondées sur la connaissance (écart-type 1,7). Aux scénarios d'évaluation de I'utilisation autodéclarée de I'EPI, les participants ont choisi des réponses correspondant à l'utilisation d'EPI conformément aux normes nationales de contrôle des infections dans une moyenne de 1,0 sur 6 scénarios (écart type $1,0)$. Les participants se sont dits plus susceptibles de porter un EPI si les patients étaient visiblement identifiés comme potentiellement contagieux avant l'évaluation du médecin, si l'équipement était accessible et si le port d'EPI devenait une priorité dans leur service d'urgence.

Conclusion: La connaissance et l'observance autodéclarée des pratiques recommandées de contrôle des infections chez les médecins d'urgence pédiatrique au Canada sont sousoptimales. L'identification précoce des patients nécessitant le port de I'EPI, un accès facile à I'EPI et une meilleure formation concernant l'isolement et les pratiques de port de I'EPI pourraient améliorer I'observance.

From the *Departments of Pediatrics and Emergency Medicine, University of Ottawa, Ottawa, ON; and tClinical Research Unit of Ottawa, Children's Hospital of Eastern Ontario Research Institute, Ottawa, ON.

Correspondence to: Dr. Sarah Reid, Children's Hospital of Eastern Ontario, 401 Smyth Road, Ottawa, ON K1H 8L1; reid_sa@cheo.on.ca.

Submitted March 11, 2010; Revised June 11, 2010; Accepted September 3, 2010

This article has been peer reviewed.

(c) Canadian Association of Emergency Physicians 
Keywords: emergency medicine, infection control, pediatric, personal protective equipment

Infections are common presenting illnesses in pediatric emergency departments (EDs). In 2009, the Children's Hospital of Eastern Ontario ED, with an annual census of 58,022, diagnosed 16,854 children $(29.0 \%)$ with respiratory or gastrointestinal infections. Such patients present an infectious risk to other patients, their families, and health care workers. Although many such infections are relatively benign and self-limited, the occurrence of severe acute respiratory syndrome (SARS) in 2003 and pH1N1 influenza in 2009 illustrate the potential for ED staff to encounter dangerous infections, with serious public health consequences. ${ }^{1,2}$ During the SARS outbreak, $42 \%$ of all Canadian cases occurred in health care workers, with the highest rates seen in those working in the EDs and intensive care units. ${ }^{3}$

Emergency physicians play a critical role in the early identification, treatment, and containment of potentially lethal pathogens. ${ }^{1}$ Personal protective equipment (PPE), consisting of gowns, gloves, respiratory and eye protection, is designed to be worn by health care workers to minimize transmission of infectious agents in the workplace. ${ }^{4}$ Hand hygiene is recognized as the best way to prevent cross-transmission of microorganisms and reduce the incidence of health care-associated infections. ${ }^{5-7}$ A recent systematic review found that in addition to hand hygiene, wearing a mask and isolating potentially infectious patients were effective in preventing the spread of respiratory virus infections, particularly in pediatric settings. ${ }^{8}$ Despite this, health care worker compliance with hand hygiene, PPE, and infection control practices remains variable and often poor. ${ }^{5,6,9-16}$

Potential barriers to maintaining infection control practices and using PPE in the ED include crowding, understaffing, lack of isolation facilities, lack of health care worker infection control education, high workload, high number of patient contacts, simultaneous management of multiple patients, high illness acuity, and significant time constraints. ${ }^{1,17}$ The ED is a highrisk area for infection transmission because of high patient turnover and the frequent lack of a patient diagnosis at the time of presentation. ${ }^{18}$ The purpose of this study was to examine the knowledge, self-reported behaviours, and barriers to compliance with infection control practices and the use of PPE in Canadian pediatric EDs.

\section{MATERIALS AND METHODS}

\section{Study Design}

This cross-sectional study surveyed emergency physicians working in Canadian pediatric EDs regarding their knowledge of infection control guidelines, use of PPE in hypothetical clinical scenarios, and perceived barriers to PPE use. The study was approved by the Research Ethics Board of the Children's Hospital of Eastern Ontario.

\section{Study Setting and Population}

All individuals listed on the Pediatric Emergency Research Canada (PERC) database of physicians practicing pediatric emergency medicine in Canada were surveyed. PERC is a collaborative Canada-wide emergency research group. ${ }^{19}$ The PERC database includes approximately $70 \%$ of all academic and nonacademic physicians working in 14 Canadian pediatric EDs who consented to have their contact information included. The annual census for participating EDs ranges from 17,000 to 65,000 .

\section{Survey Instrument}

A survey instrument was developed in accordance with the methods advocated by both Nunnally and Bernstein and Streiner and Norman (Appendix). ${ }^{20,21}$ The survey (available at <http://www.cjem-online. $\mathrm{ca}>$ ) consisted of 21 questions covering demographics and knowledge and behaviour regarding the use of PPE. The instrument was pilot tested for readability, face validity, and ease of use on a convenience sample of emergency physicians and pediatricians and was refined based on the feedback received. In addition to four demographic questions, the survey included nine single-selection closed-ended questions on whether infection control manuals were available and how often they were used, participants' experience with SARS, and when participants were last fitted for an N95 respirator and received PPE training. Using a Likert scale, participants were asked how comfortable they were with their knowledge of transmission-based isolation practices and how many times they wore PPE during the winter (traditional pediatrics respiratory "viral season") of 2006-2007. Three questions captured information regarding the extent to which a variety of factors influenced the choice to follow or not 
follow PPE guidelines or would be deemed to help participants follow PPE guidelines in the future. One question presented six clinical scenarios illustrating typical infectious diseases and asked participants to select which PPE, if any, they would typically use in such scenarios. Finally, participants' knowledge of transmission-based isolation practices was evaluated by questions relating to the appropriate infection control precautions that would apply to 11 infections commonly seen in pediatric EDs. The definitions for each type of infection control precaution (such as contact, droplet, and airborne precautions) were provided..$^{22}$

\section{Study Protocol}

A presurvey announcement was made to survey recipients via e-mail. Recipients were subsequently mailed the survey instrument in June 2007. A modified Dillman method was used for contact and follow-up procedures..$^{23}$ Nonresponders received second and third direct mailings. Participants and sites were identified only by a study number. Investigators were blinded to study number assignment to ensure participant confidentiality.

\section{Measurements/Key Outcome Measures}

Outcomes included participant knowledge of transmissionbased infection control guidelines, reported use of PPE for clinical infectious disease scenarios, and factors that influenced choice to follow or not follow PPE guidelines. To further explore reported use of PPE, participants were also asked to estimate how often they wore different types of PPE (mask, gloves, gown, eye protection) while assessing febrile respiratory patients during the previous viral season. Factors that would improve future compliance with $\mathrm{PPE}$ guidelines and correlations between knowledge and perceived comfort with PPE, age, recent PPE training, experience with SARS, or site were also examined.

\section{Sample Size}

Because all individuals in the population of interest were invited to participate, this survey is best considered to be a census. As such, our sample size was determined by the finite number of emergency physicians registered in the PERC database who participated.

\section{Data Entry and Analysis}

Data entry and analysis were performed using SPSS 16.0.0 (SPSS Inc, Chicago, IL). Twenty percent of the sample was randomly chosen for double entry and verification. Descriptive statistics were used to characterize variables such as length of time since graduation from medical school and years of practice in the ED. Response rates were calculated, overall and by site. Frequencies of responses to survey items that solicited information regarding physician training, knowledge, and use of PPE were tallied. Correlations were measured using the Kendall rank correlation coefficient. The Wilcoxon rank sum test was used for two-group comparisons of ordinal scores; the KruskalWallis test was used for comparisons involving more than two groups of ordinal scores. Two-sided tests were used throughout, and $p$ values less than 0.05 were considered statistically significant. No adjustment for multiple comparisons was performed.

\section{RESULTS}

\section{Respondents}

At the 14 children's hospitals surveyed, 186 eligible participants were identified and 123 returned completed surveys, for an overall response rate of $66.1 \%$. Table 1 summarizes participants' demographic information.

\section{Training and Resources}

Twenty-two percent of participants reported that they had never received PPE training and/or been fitted for a N95 respirator and 32\% had not been trained and/or fit-tested in the previous 2 years. Of the 82 (66.7\%) participants who reported access to an infection

\begin{tabular}{|c|c|}
\hline Age in years, median (range) & $40(30-67)$ \\
\hline Male, $n(\%)$ & $58(47.2)$ \\
\hline Years in practice, median (range) & $9(0-32)$ \\
\hline \multicolumn{2}{|l|}{ Training, $n(\%)$} \\
\hline Pediatrics & $50(40.7)$ \\
\hline Pediatrics + PEM fellowship & 49 (39.8) \\
\hline Other & $24(19.5)$ \\
\hline $\begin{array}{l}\text { Experience working with potential/actual } \\
\text { SARS patients, } n(\%)\end{array}$ & $78(64.5)$ \\
\hline
\end{tabular}


control manual, 14 (17.1\%) reported that they used it more than once per year and $36(43.9 \%)$ reported that they had never used it.

\section{Knowledge}

Table 2 provides information on participants' selfreported behaviour and knowledge of isolation precautions. Participants were correct on a mean of 4.9 of 11 knowledge-based questions (SD 1.7). Sixty-five participants $(52.9 \%)$ indicated that they were very or somewhat comfortable with their knowledge of these guidelines, whereas 32 (26.0\%) indicated that they were very or somewhat uncomfortable. The remaining 26 respondents $(21.1 \%)$ indicated that they were neutral regarding their knowledge. No significant correlation was found between knowledge score and comfort with knowledge of infection control guidelines (Kendall rank correlation $0.07 ; p=0.33$ ), age (Kendall rank correlation $0.06 ; p=0.40$ ), more recent PPE training (Kendall rank correlation $0.06 ; p=0.42$ ), experience with SARS (Wilcoxon rank sum test, $p=$ 0.33 ), or site (Kruskal-Wallis test, $p=0.31$ ).

\section{Self-Reported PPE Use}

Using 6 clinical infectious disease scenarios to assess respondents' use of PPE in their daily practice, participants reported PPE use in accordance with national standards in a mean of 1.0 of 6 scenarios (SD 1.0). Scenario 2 described a febrile respiratory patient, and whereas $95 \%$ of participants indicated that they would use hand hygiene before assessing the patient, only $9.8 \%$ would use gloves, $11.4 \%$ would use a regular

Table 2. Self-reported behaviour and knowledge of isolation precautions

\begin{tabular}{|c|c|c|}
\hline \multicolumn{3}{|c|}{ Self-reported behaviour } \\
\hline Scenario & National standard ${ }^{22}$ & $\begin{array}{l}\text { Reported to follow national standard } \\
n / N \text { respondents (\%) }\end{array}$ \\
\hline $\begin{array}{l}\text { Assessing an 8-month-old with fever, } \\
\text { vomiting, and diarrhea }\end{array}$ & $\begin{array}{l}\text { Hand hygiene, regular gloves, clean } \\
\text { gown }\end{array}$ & $6 / 123(4.9)$ \\
\hline $\begin{array}{l}\text { Assessing a 4-year-old asthmatic with URTI, } \\
\text { increasing respiratory distress, and fever }\end{array}$ & $\begin{array}{l}\text { Hand hygiene, regular gloves, surgical } \\
\text { mask, clean gown, eye protection }\end{array}$ & $0 / 123(0.0)$ \\
\hline $\begin{array}{l}\text { Performing a lumbar puncture on a febrile } \\
\text { 2-week-old }\end{array}$ & $\begin{array}{l}\text { Hand hygiene, sterile gloves, surgical } \\
\text { mask, sterile gown }\end{array}$ & 10/122 (8.1) \\
\hline $\begin{array}{l}\text { Assessing a 10-year-old involved in a motor } \\
\text { vehicle collision }\end{array}$ & $\begin{array}{l}\text { Hand hygiene, regular gloves, surgical } \\
\text { mask, clean gown, eye protection }\end{array}$ & $21 / 122(17.1)$ \\
\hline Performing a urine dipstick test & Hand hygiene, regular gloves & $67 / 123(54.5)$ \\
\hline $\begin{array}{l}\text { Intubating a 16-year-old with a toxic } \\
\text { ingestion }\end{array}$ & $\begin{array}{l}\text { Hand hygiene, regular gloves, surgical } \\
\text { mask, eye protection }\end{array}$ & 20/121 (16.3) \\
\hline \multicolumn{3}{|c|}{ Knowledge of isolation precautions } \\
\hline Scenario & Correct isolation precautions ${ }^{22}$ & $\begin{array}{c}\text { Chose correct isolation precaution } \\
n / N \text { respondents (\%) }\end{array}$ \\
\hline Suspected pulmonary tuberculosis & Airborne & $50 / 122(40.7)$ \\
\hline Febrile neutropenia & Hand hygiene & $7 / 122(5.7)$ \\
\hline Suspected meningococcal meningitis & Droplet \pm contact & $63 / 122(51.2)$ \\
\hline Chickenpox & Contact + airborne & $4 / 122(3.3)$ \\
\hline Respiratory syncytial virus bronchiolitis & Contact + droplet & $15 / 122(12.2)$ \\
\hline Rotavirus & Contact & $91 / 122(74)$ \\
\hline $\begin{array}{l}\text { Methicillin-resistant Staphylococcus } \\
\text { aureus colonized or infected }\end{array}$ & Contact \pm mask & $85 / 122(69.1)$ \\
\hline Mild cellulitis in healthy patient & Hand hygiene & $90 / 122(73.2)$ \\
\hline Clostridium difficile & Contact & $101 / 122(82.1)$ \\
\hline Suspected influenza & Contact + droplet & $12 / 122(9.8)$ \\
\hline Norwalk virus & Contact & $87 / 122(70.7)$ \\
\hline
\end{tabular}




\begin{tabular}{|c|c|}
\hline \multirow[b]{2}{*}{ Factor influencing use of PPE } & $\begin{array}{l}\text { Identified as moderate/ } \\
\text { significant influence }\end{array}$ \\
\hline & $n / N$ respondents (\%) \\
\hline $\begin{array}{l}\text { Patient identified before I enter } \\
\text { room }\end{array}$ & $104 / 120(86.7)$ \\
\hline $\begin{array}{l}\text { Information on what to wear is } \\
\text { easily accessible }\end{array}$ & $97 / 121(80.2)$ \\
\hline Equipment is available in ED & $113 / 121(93.4)$ \\
\hline Equipment is convenient & $112 / 121(92.6)$ \\
\hline Hand hygiene is convenient & $107 / 122(87.7)$ \\
\hline PPE is a priority in my ED & $99 / 120(82.5)$ \\
\hline $\begin{array}{l}\text { My colleagues follow the } \\
\text { guidelines }\end{array}$ & $79 / 119(66.4)$ \\
\hline I receive regular PPE training & $72 / / 117(61.5)$ \\
\hline $\begin{array}{l}\text { I want to protect myself and my } \\
\text { family }\end{array}$ & $118 / 122(96.7)$ \\
\hline I want to protect my patients & $119 / 122(97.5)$ \\
\hline $\begin{array}{l}\text { I had input into creation of } \\
\text { guidelines }\end{array}$ & 29/115 (24.9) \\
\hline \multirow[b]{2}{*}{ Factor influencing not using PPE } & $\begin{array}{l}\text { Identified as moderate/ } \\
\text { significant influence }\end{array}$ \\
\hline & $n / N$ respondents (\%) \\
\hline $\begin{array}{l}\text { Patient not identified before I } \\
\text { enter room }\end{array}$ & $93 / 118(87.3)$ \\
\hline I am not sure what to wear & 71/119 (59.7) \\
\hline Equipment is not available in ED & $74 / 117(63.2)$ \\
\hline Equipment is not convenient & $77 / 119(64.8)$ \\
\hline Hand hygiene is not convenient & $58 / 118(49.1)$ \\
\hline PPE takes too long & $77 / 120(62.5)$ \\
\hline $\begin{array}{l}\text { PPE is not feasible given volume } \\
\text { of patients }\end{array}$ & $78 / 120(65.0)$ \\
\hline PPE interferes with patient care & $62 / 119(52.1)$ \\
\hline PPE frightens children & $68 / 120(56.6)$ \\
\hline My colleagues do not use PPE & $60 / 120(50.0)$ \\
\hline PPE is not a priority in my ED & 66/118 (55.9) \\
\hline $\begin{array}{l}\text { Guidelines are unreasonable/ } \\
\text { impractical }\end{array}$ & 73/119 (61.3) \\
\hline Guidelines are out of date & $51 / 116(44.0)$ \\
\hline \multirow{2}{*}{$\begin{array}{l}\text { Factor that would help me use } \\
\text { PPE more }\end{array}$} & $\begin{array}{l}\text { Identified as moderate/ } \\
\text { significant influence }\end{array}$ \\
\hline & $n / N$ respondents (\%) \\
\hline $\begin{array}{l}\text { Patient identified before I enter } \\
\text { room }\end{array}$ & $109 / 120(90.8)$ \\
\hline $\begin{array}{l}\text { Information of what to wear is } \\
\text { easily accessible }\end{array}$ & $108 / 120(90.0)$ \\
\hline Equipment is available in ED & $111 / 120(92.5)$ \\
\hline Equipment is convenient & $108 / 120(90.0)$ \\
\hline Hand hygiene is convenient & $104 / 120(86.7)$ \\
\hline $\mathrm{PPE}$ is a priority in my ED & $110 / 120(91.6)$ \\
\hline My colleagues follow guidelines & $98 / 120(78.3)$ \\
\hline I receive regular PPE training & $97 / 120(80.8)$ \\
\hline I or my family became sick & $108 / 120(90.0)$ \\
\hline
\end{tabular}

\begin{tabular}{l}
\hline Table 3. Continued \\
\hline $\begin{array}{l}\text { Factor that would help me use } \\
\text { PPE more }\end{array}$ \\
$\begin{array}{l}\text { Identified as moderate/ } \\
\text { significant influence }\end{array}$ \\
$\begin{array}{l}\text { I contaminated one of my patients } \\
\text { I had input into creation of } \\
\text { guidelines }\end{array}$ \\
\hline $\begin{array}{l}\text { ED }=\text { emergency department; PPE }=\text { personal protective equipment. } \\
\text { Participants could select more than one response. }\end{array}$ \\
\hline
\end{tabular}

mask, $3.3 \%$ would use a clean gown, and $3.3 \%$ would use eye protection. When asked specifically about their use of PPE while assessing febrile respiratory patients during the 2006-2007 winter season, 13 (10.5\%) participants reported always or usually wearing a mask, $9(7.4 \%)$ reported always or usually wearing gloves, 5 (4.1\%) reported always or usually wearing a gown, and $15(12.3 \%)$ reported always or usually wearing eye protection. A small but statistically significant negative correlation between self-reported behaviour for the clinical scenarios and knowledge score was found (Kendall rank correlation $-0.15 ; p=0.05$ ). No significant correlations were found between selfreported behaviour and age (Kendall rank correlation $0.05 ; p=0.48$ ), recent PPE training (Kendall rank correlation $-0.06 ; p=0.46)$, experience with SARS (Wilcoxon rank sum test, $p=0.51$ ), perceived comfort with knowledge (Kendall rank correlation $0.03 ; p=$ 0.74 ), or site (Kruskal-Wallis test, $p=0.15$ ).

\section{Factors Influencing PPE Use}

Table 3 summarizes information on the influence of various factors on the use of PPE. The factors reported to have the strongest influence on the decision to wear PPE were PPE being available and convenient and the desire to protect oneself, one's family, and one's patients. A number of factors were identified as influencing the decision not to use PPE despite the existence of guidelines recommending their use, the most frequently cited being the fact that the patient was not identified as possibly having a communicable disease prior to physician assessment. Participants also identified a number of factors that they believed would aid them in using PPE in accordance with guidelines in the future, the most significant of which were knowledge that the physician had transmitted an infection to a patient in the past or illness acquired by the physician (or a family member) that could be attributed to the physician not using PPE. 


\section{Self-Reported Infection Rates}

Ninety-one percent of respondents reported having three or fewer episodes of acute gastroenteritis or respiratory tract infection in the previous 12 months, and $81 \%$ reported not missing any days of work in the previous 12 months owing to illness.

\section{DISCUSSION}

To our knowledge, this study provides the first examination of knowledge, self-reported behaviour, and perceived barriers to compliance with infection control practices and the use of PPE in Canadian pediatric EDs. Our results indicate that a significant lack of knowledge exists regarding infection control guidelines and PPE use among Canadian pediatric emergency physicians. The validity of our findings is supported by our $66.1 \%$ response rate and the inclusive nature of the study sample. Our findings are consistent with other studies that have found variable and often poor infection control knowledge among health care workers in general. ${ }^{13-16,24} \mathrm{We}$ found no significant correlation between perceived comfort with knowledge and actual knowledge of transmission-based infection control practices. This suggests that a gap exists between selfassessment and actual knowledge of infection control precautions. This gap that may lead clinicians to exclude infection control in their continuing medical education activities, thus perpetuating their lack of knowledge and putting themselves and their patients at risk.

Knowledge of isolation precautions was greatest in scenarios involving gastrointestinal infection but very low among other common pediatric infections, such as respiratory syncytial virus bronchiolitis and varicella. Although only a small number of participants were correct in identifying hand hygiene as the sole appropriate infection control precaution required for patients with febrile neutropenia, the overwhelming majority of respondents incorrectly indicated that reverse isolation was also required, indicating that infection control precautions for such patients would be unnecessarily excessive. A small negative correlation was identified between self-reported PPE use and knowledge score. It is not clear how poorer knowledge of infection control and PPE guidelines might be associated with improved self-reported compliance with PPE guidelines. This has not been found in previous studies and may well be a spurious association given the numerous uncorrected comparisons we performed.
Overall, participants displayed poor compliance with infection control guidelines in their self-reported use of PPE in common patient scenarios. Despite contact precautions having the highest scores correct for knowledge, pediatric emergency physicians still rarely reported using these precautions when caring for ED patients with gastroenteritis. Given the burden of this disease in the pediatric population and the ease with which nosocomial infection can be transmitted, this is a worrisome finding. Compliance was reported to be highest when assessing trauma patients. This may be due to a perceived higher risk of exposure to blood, body fluids, and bloodborne pathogens. Although hand hygiene and PPE are well documented to be effective in preventing transmission of respiratory infections in the pediatric population, ${ }^{8}$ in our study, self-reported PPE use was poor for febrile respiratory patients. This finding may reflect the high volume of patients seen in the pediatric ED during "viral season," the need for multiple and ongoing assessments, and/or the fact that PPE is deemed to be inconvenient and time-consuming.

Our results indicate that many factors may moderately or considerably influence behaviour around the use of PPE. Although the decision by a physician to use or not to use PPE when seeing a given patient is undoubtedly multifactorial, a number of changes could be instituted by individual EDs in an attempt to increase adherence to PPE guidelines, including identifying patients with complaints that require PPE use prior to the physician entering the room, identifying the type of PPE advised, and making PPE available and convenient. Making PPE a priority in the ED was identified by participants as a significant factor influencing PPE use. This echoes the organizational and cultural changes that have been found to be effective in improving hand hygiene. ${ }^{5,25-27}$ A recent Cochrane review provides support for the use of local opinion leaders in the successful promotion of evidence-based practice..$^{28}$ Despite the fact that we did not find recent PPE training to be correlated with knowledge, respondents felt that receiving ongoing education around PPE and infection control would help them use PPE more. The modest positive effect of educational interventions for improving hand hygiene and $\mathrm{PPE}$ adherence has been shown in previous studies. , $24,26,29-31^{2}$

The primary limitation of this study is its reliance on self-reporting. It is almost certain that direct observational assessment of PPE use at individual sites would have provided more accurate information regarding the 
use of PPE by pediatric emergency physicians. To this end, we plan to examine actual PPE use and adherence in a future observational study. Because it is likely that self-reported behaviour would be better than actual behaviour, it is probable that our results overestimate the current use of PPE in Canadian pediatric EDs.

This study was performed prior to the onset of pH1N1 influenza. In the future, it would be interesting to assess knowledge, self-reported behaviour, and perceived barriers to adherence to PPE guidelines in a postpandemic environment. Given the heightened awareness during such events, it is likely that PPE education and N95 fit-testing levels would be higher, perhaps translating into improved general knowledge of infection control guidelines. Future research examining PPE knowledge and behaviour in pediatric emergency nurses would aid in understanding the entire picture of safety and adherence to PPE guidelines in Canadian pediatric EDs.

\section{CONCLUSION}

Canadian pediatric emergency physicians have suboptimal knowledge regarding infection control and use of PPE and are relatively unaware of their knowledge gap. Self-reported use of PPE is not in accordance with infection control guidelines, and such lapses put physicians and their patients at risk. Individual pediatric EDs may be able to improve compliance with guidelines with improved and regular education programs, convenient and accessible PPE, an emphasis on hand hygiene, and the development of a pro-PPE culture. With such changes, Canadian pediatric EDs may be better prepared to deal with novel and high-risk infectious diseases, providing a safe environment for health care workers and patients alike.

Acknowledgement: We express our gratitude to the physicians who took time out of their busy schedules to participate in this study. We also gratefully acknowledge the work of Jennifer Spruyt and Candice McGahern on this project.

Competing interests: None declared.

\section{REFERENCES}

1. Rothman RE, Irvin CB, Moran GJ, et al. Respiratory hygiene in the emergency department. Ann Emerg Med 2006;48:570-82.

2. Kumar A., Zarychanski R, Pinto R, et al. Critically ill patients with 2009 influenza A (H1N1) infection in Canada. FAMA 2009;302:1872-9.
3. Varia M, Wilson S, Sarwal S, et al. Investigation of a nosocomial outbreak of severe acute respiratory syndrome (SARS) in Toronto, Canada. CMA7 2003;169:285-92.

4. Designing an effective PPE program. Canadian Centre for Occupational Health and Safety. Available at: http://www. ccohs.ca/oshanswers/prevention/ppe/designin.html (accessed February 26, 2010).

5. Pittet D, Hugonnet S, Mourouga P, et al. Effectiveness of a hospital-wide programme to improve compliance with hand hygiene. Infection Control Programme. Lancet 2000;356: 1307-12.

6. Boyce JM, Pittet D. Guideline for hand hygiene in healthcare settings. Recommendations of the Healthcare Infection Control Practices Advisory Committee and the HICPAC/ SHEA/APIC/IDSA Hand Hygiene Task Force. Society for Healthcare Epidemiology of America/Association for Professionals in Infection Control/Infectious Diseases Society of America. MMWR Recomm Rep 2002;51:1-45.

7. Centers for Disease Control and Prevention. Guidelines for the prevention and control of nosocomial infections: guideline for handwashing and hospital environmental control. Atlanta (GA): US Public Health Service; 1985.

8. Jefferson T, Del Mar C, Dooley L, et al. Physical interventions to interrupt or reduce the spread of respiratory viruses. Cochrane Database Syst Rev 2010;(1):CD006207.

9. Albert RK, Condie F. Hand-washing patterns in medical intensive-care units. N Engl 7 Med 1981;304:1465-6.

10. Pittet D, Mourouga P, Perneger TV. Compliance with handwashing in a teaching hospital. Infection Control Programme. Ann Intern Med 1999;130:126-30.

11. Donowitz LG. Handwashing technique in a pediatric intensive care unit. Am 7 Dis Child 1987;141:683-5.

12. Raju TN, Kobler C. Improved handwashing habits in the newborn nurseries. Am 7 Med Sci 1991;302:355-8.

13. Courington KR, Patterson SL, Howard RJ. Universal precautions are not universally followed. Arch Surg 1991; 126:93-6.

14. Ros SP, Cabrera-Ros BL. Poor compliance with universal precautions: a universal phenomenon? Pediatr Emerg Care 1990;6:183-5.

15. Moore S, Goodwin H, Grossberg R, et al. Compliance with universal precautions among pediatric residents. Arch Pediatr Adolesc Med 1998;152:554-7.

16. Jusot JF, Vanhems P, Benzait F, et al. The procedures of hygiene to control hospital-acquired diarrhea in paediatric wards: a multicentre audit. 7 Hosp Infect 2004;57:44-51.

17. Meengs MR, Giles BK, Chisholm CD, et al. Hand washing frequency in an emergency department. Ann Emerg Med 1994;23:1307-12.

18. Parker MJ, Goldman RD. Paediatric emergency department staff perceptions of infection control measures against severe acute respiratory syndrome. Emerg Med 7 2006;23:349-53.

19. Pediatric Emergency Research Canada website. Available at: http://perc.srv.ualberta.ca/ (accessed February 26, 2010).

20. Nunnally JC, Bernstein IH. Psychometric theory New York: McGraw-Hill; 1994.

21. Streiner DL, Norman GR. Health measurement scales: a practical guide to their development and use New York: Oxford University Press; 1989. 
22. Health Canada. Routine practices and additional precautions for preventing the transmission of infection in health care. Can Commun Dis Rep 1999;25 Suppl 4:1-155. Available at: http://www.phac-aspc.gc.ca/publicat/ccdr-rmtc/99pdf/ cdr25s4e.pdf (accessed February 26, 2010).

23. Dillman D. Mail and Internet surveys: the tailored design method New York: John Wiley \& Sons; 2000.

24. Sax H, Perneger T, Hugonnet S, et al. Knowledge of standard and isolation precautions in a large teaching hospital. Infect Control Hosp Epidemiol 2005;26:298-304.

25. Pittet D, Simon A, Hugonnet S, et al. Hand hygiene among physicians: performance, beliefs and perceptions. Ann Intern Med 2004;141:1-8.

26. Larson EL, Early E, Cloonan P, et al. An organizational climate intervention associated with increased handwashing and decreased nosocomial infections. Behav Med 2000;26:14-22.
27. Lankford MG, Zembower TR, Trick WE, et al. Influence of role models and hospital design on hand hygiene of healthcare workers. Emerg Infect Dis 2003;9:217-23.

28. Doumit G, Gattellari M, Grimshaw J, et al. Local opinion leaders: effects on professional practice and health care outcomes. Cochrane Database Syst Rev 2007;(1):CD000125.

29. Whitby M, McLaws ML, Slater K, et al. Three successful interventions in health care workers that improve compliance with hand hygiene: is sustained replication possible? Am 7 Infect Control 2008;36:349-55.

30. Williams CO, Campbell S, Henry K, et al. Variables influencing worker compliance with universal precautions in the emergency department. Am 7 Infect Control 1994;22: $138-48$.

31. Pittet D. The Lowbury Lecture: behaviour in infection control. 7 Hosp Infect 2004;58:1-13. 